\title{
Analisis Kepadatan Lalu Lintas Berdasarkan Pengaturan Traffic light (Studi Kasus Perempatan Bandar Kidul Kota Kediri)
}

\author{
Mohammad Khoiruddin Fauzi ${ }^{\left({ }^{*}\right)}$, Heribertus Budi Santoso ${ }^{(2)}$, ,Sri Rahayuningsih ${ }^{(3)}$ \\ ${ }^{(1,2,3)}$ Program Studi Teknik Industri,Universitas Kadiri \\ Email : fauzim99@gmail.com ${ }^{(1)}$
}

\begin{abstract}
Abstrak
Pengaturan lampu lalu lintas di persimpangan jalan untuk mengatur kelancaran arus kendaraan dan juga mengakomodasi tiap kepentingan pengguna jalan. Tujuan penelitian untuk menganalisis tingkat kepadatan kendaraan di persimpangan Bandar Kidul Kota Kediri berdasarkan pengaturan traffic light. Populasi penelitian yaitu seluruh kendaraan yang melewati Simpang Empat Bandar Kidul. Sampel penelitian yaitu kendaraan yang melewati persimpangan Bandar Kidul, dengan waktu pengamatan sejak 2-3 Juli 2017 pada pagi, siang dan sore masing-masing selama satu jam pengamatan. Data dianalisis dengan metode Greenshield dan metode Webster. Hasil analisis model Greenshield pada pagi arah masuk dari Jalan Bandar Ngalim memiliki volume maksimum yaitu $\mathrm{V}_{\max }$ 303,58 smp/jam/lajur menuju jalan KH Wachid Hasyim dan jalan KH Agus Salim, sedangkan volume maksimum di Bandar Ngalim pada sore yaitu $\mathrm{V}_{\max }$ 191,51Smp/Jam/lajur. Sedangkan pada model Webster, waktu nyala lampu hijau fase 1 29,37 detik, nyala lampu fase 2 29,98 detik, nyala lampu hijau fase 3 sebesar 31,56 detik dan nyala lampu hijau fase 4 sebesar 31,33 detik. Sedangkan nyala lampu merah fase 197,80 detik, nyala lampu merah fase 297,20 detik, nyala lampu merah fase 3 95,69 detik, dan nyala lampu merah fase 4 95,80 detik.
\end{abstract}

Kata Kunci: Kepadatan Lalu Lintas, Pengaturan Traffic light

\begin{abstract}
Traffic lights at the crossroads to regulate the smooth flow of vehicles and also accommodate each of the interests of road users. The purpose of the study was to analyze the level of vehicle density at the Bandar Kidul City Kediri junction based on traffic light settings. The study population is all vehicles that pass the Simpang Empat Bandar Kidul. The research sample is a vehicle that passes through the intersection of Bandar Kidul, with observation time since July 2-3, 2017 in the morning, afternoon and evening for one hour each observation. Data were analyzed by the Greenshield method and the Webster method. The results of the Greenshield model analysis on the morning of the direction of entry from Bandar Ngalim Road have a maximum volume of Vmax $303.58 \mathrm{pcu} /$ hour / lane to the KH Wachid Hasyim road and KH Agus Salim road, while the maximum volume at Bandar Ngalim in the afternoon is Vmax 191.51Smp / Hours / lane. Whereas in the Webster model, the time for phase 1 green light is 29.37 seconds, phase 2 is 29.98 seconds, phase 3 is 31.56 seconds and phase 4 is 31.33 seconds. While the phase 1 red lights 97.80 seconds, the phase 2 red lights 97.20 seconds, the phase 3 red lights 95.69 seconds, and the phase 4 red lights 95.80 seconds.
\end{abstract}

Keyword : Traffic Density, Traffic light Settings 


\section{Pendahuluan}

Lampu lalu lintas merupakan alat pemberi isyarat lalu lintas atau (APILL) yang merupakan lampu yang mengendalikan arus lalu lintas yang terpasang dipersimpangan jalan, tempat penyeberangan pejalan kaki (zebra cross), dan tempat arus lalu lintas lainnya [1], [2]. Lampu ini yang menandakan kapan kendaraan harus berjalan dan berhenti secara bergantian dari berbagai arah. Pengaturan lalu lintas dipersimpangan jalan dimaksudkan untuk mengatur pergerakan kendaraan pada masing-masing kelompok pergerakan kendaraan agar dapat bergerak bergantian sehingga tidak saling mengganggu antar arus yang ada [3]-[5], [6]-[8]. Namun keberadaan lampu lalu lintas diperkotaan masih kurang efektif dikarenakan volume kendaraan yang tidak seimbang . Tidak hanya pada jam-jam sibuk atau hari libur bahkan pada jam normal volume kendaraan bisa menjadi padat atau sebaliknya. Perubahan kepadatan arus lalu lintas seperti ini tentu tidak mampu secara pasti diprediksi oleh traffic light [1], [9], [10], [11] Sampai saat ini sistem pengaturan lampu lalu lintas di sebagian besar persimpangan di Indonesia masih menggunakan sistem pengaturan lampu lalu lintas fixed time [12], [13], [2]. Sistem pengaturan lampu lalu lintas model fixed time merupakan sistem pengaturan lampu lalu lintas dengan menggunakan aturan waktu yang telah ditetapkan sebelumnya, dengan mempertimbangkan beberapa hal sesuai teknis dan regulasi yang ada. Namun demikian perkembangan dan pertumbuhan arus dan volume kendaraan yang sangat dinimasi ternyata tidak mampu direspon dengan cepat pengaturan model tersebut [14],[15]. Efek yang paling nyata dari kondisi itu menyebabkan antrian yang cukup panjang jika volume kendaraan di salah satu persimpangan cukup padat, namun traffic light menggunakan waktu nyala yang tetap. Sistem ini masih belum efisien karena memunculkan kemacetan di salah satu persimpangan [9], [16], [17]. Melihat pentingnya peranan lampu lalu lintas dalam pengaturan kelancaran lalu lintas, dibutuhkan rekayasa suatu sistem yang dapat mengatasi kemacetan di salah satu persimpangan bervolume kendaraan padat [18],[19], [20]. Sistem pengaturan lalu lintas yang baik akan secara otomatis menyesuaikan diri dengan kepadatan arus lalu lintas pada jalur yang diatur [21]. Salah satu analisis yang bisa digunakan adalah metode Webster dapat digunakan untuk menyelesaikan masalah tersebut. Metode Webster ini menghasilkan nilai output berupa lamanya waktu-nyala dari lampu hijau berdasarkan kepadatan volume kendaraan di setiap persimpangan [22], [23]. Selanjutnya juga akan dilakukan analisis menggunakan metode [4], [12] untuk melihat hubungan antara volume kendaraan, kecepatan dan kepadatan arus lalu lintas. Secara teoritis volume kendaraan yang tinggi menyebabkan penurunan kecepatan, kendaraan melambat. Efek dari kecepatan yang menurun maka mengakibatkan arus lalu lintas semakin padat [13], [24], [25], [26].

\section{Metode Penelitian}

Penelitian ini dilakukan di Simpang Empat Bandar Kidul Kota Kediri, secara spesifik simpang empat ini berada pada titik persimpangan antara Jalan Bandar Ngalim di sebelah timur, Jalan KH. Agus Salim di sebelah barat. Sedangkan disebelah utara merupakan Jalan KH. Wachid Hasyim, sedangkan di sebelah selatan merupakan Jalan KH. Hasyim Asy'ari. dipilihnya simpang empat ini berdasarkan pengamatan yang dilakukan peneliti memenuhi kriteria kepadatan lalu lintas yang peneliti tetapkan sehingga sesuai dijadikan lokasi penelitian. Waktu penelitian ini direncanakan selama satu bulan yaitu selama bulan Agustus 2017. Dengan melakukan survey di lapangan untuk melihat tingkat kepadatan lalu lintas jalan, serta memetakan kepadatan jumlah kendaraan yang melewati persimpangan Bandar Kidul tersebut [27]-[29].

Dalam penelitian ini data primer diambil langsung ke lokasi penelitian dengan melakukan survey melakukan pengamatan terhadap kepadatan lalu lintas di perempatan Bandar Kidul Kota Kediri. Data sekunder penelitian ini berupa peraturan lalu lintas penerapan traffic light di jalan raya, dan juga penelitian terdahulu dalam bentuk jurnal, karya ilmiah lain yang memiliki kesamaan tema penelitian dan memiliki relevansi dengan penelitian ini.

Pengumpulan data dengan pengamatan langsung pada objek sehingga memungkinkan untuk mengamati secara bertahap disertai pencatatan singkat dan jelas sehingga data yang diperoleh dapat dipercaya. Pengumpulan data yang dilakukan dengan mencatat atau menggunakan data baik seluruhnya maupun sebagian dari perpustakaan, berupa buku, catatan ataupun arsip-arsip yang berhubungan 
dengan pengaturan traffic light dan penelitian yang memiliki tema yang sama dengan penelitian ini. Adapun yang menjadi sampel penelitian ini adalah sebagian kendaraan yang melewati simpang empat Bandar Kidul pada waktu dilakukan pengamatan penelitian tanggal 2-3 Juli 2017 pada pengamatan pagi jam 06.00-07.00 WIB , siang jam 12.00-13.00 WIB dan sore jam 16.00-17.00 WIB masing-masing selama satu jam pengamatan.

Metode pengolahan data menggunakan pendekatan kuantitatif deskriptif, hal tersebut berdasarkan data yang ada berbentuk angka atau kuantitatif dianalisis dengan cara mengaplikasikannya dalam berbagai rumus-rumus yang sesuai dengan desain penelitian [30], [31].

Teknik analisa data adalah cara melaksanakan analisis terhadap data dengan tujuan mengolah alat tersebut menjadi informasi, sehingga karakteristik atau sifat-sifat datanya dapat dengan mudah dipahami dan bermanfaat menjawab masalah yang ada dalam penelitian. Adapun analisis yang digunakan adalah metode Webster dan Metode Greenshields :

(1) Metode Webster

Metode ini dikembangkan di Road Research Laboratory (RRL), Inggris pada awal tahun 1960-an dan merupakan pertama untuk menganalisis kinerja persimpangan bersinyal. Tundaaan rata-rata pada suatu persimpangan yang diatur dengan sinyal waktu tetap dapat dihitung dengan [22], [23] :

$$
d=\frac{C(1-\gamma)^{2}}{2(1-\gamma x)}+\frac{x^{2}}{2 q(1-x)}-0,65\left(\frac{c}{q^{2}}\right)^{\frac{1}{3}} x^{(2+5 \lambda)}
$$

Keterangan :

$\mathrm{d}=$ tundaan rata - rata per kendaraan

$\mathrm{c}=$ waktu siklus (detik)

$\lambda=$ proporsi waktu hijau efektif

$\mathrm{q}=$ arus jenuh

$\mathrm{x}=$ derajat kejenuhan (perbandingan arus maksimum yang didapat dari garis stop)

(2) Metode Greenshields

Greenshields merumuskan bahwa hubungan matematis antara kecepatan-kepadatan diasumsikan linear [4], [12]seperti yang dinyatakan dalam persamaan :

Keterangan :

$$
S=S f f-\frac{S f f}{D j} \cdot D
$$

$\mathrm{S}=$ kecepatan $(\mathrm{km} / \mathrm{jam})$

Sff = kecepatan pada kondisi lalu lintas renda atau pada kondisi kepadatan mendekati nol atau kecepatan mendekati nol atau kecepatan arus bebas $(\mathrm{km} / \mathrm{jm})$

$\mathrm{Dj}=$ kepadatan kondisi arus lalu lintas macet total $(\mathrm{kend} / \mathrm{km})$

Kemudian persamaan yang menyatakan hubungan matematis antara arus - kecepatan di kondisi arus maksimum/kapasitas (VM) didapatkan persamaan [4],[19] :

$$
S=\frac{D j . S f f}{4}
$$

Pada kondisi kepadatan maksimum (DM) didapatkan dengan persamaan [19], [25]:

$$
D M=\frac{D j}{2}
$$

Pada kondisi kepadatan maksimum (DM) didapatkan dengan persamaan [4], [19], [25]:

$$
S M=\frac{S f f}{2}
$$




\section{Hasil dan Pembahasan}

Didapatkan hasil pada penelitian sebagai berikut :

1. Visualisasi Grafik Kepadatan pada Masing-Masing Jalan di Persimpangan

a. Visualisasi Kepadatan Lalu Lintas Hari Minggu (kepadatan minimum)

Kepadatan lalu lintas pada hari libur menunjukkan penurunan yang luar biasa mengingat volume kendaraan berkorelasi dengan aktifitas hari efektif masyarakat, jumlah kendaraan mengalami penurunan volume yang cukup signifikan [32], [33], terlihat tingkat kepadatan masih dibawah $400 \mathrm{smp} / \mathrm{jam}$. Volume kendaraan roda empat pada jalan Bandar Ngalim terlihat mendominasi baik pada waktu pagi hari sampai sore hari. Sedangkan pada lajur jalan KH. Agus Salim cenderung sedikit pada semua jenis kendaraan. Selanjutnya pada jalan KH. Wachid Hasyim volume tertinggi pada jenis kendaraan sepeda motor. Sedangkan pada jalan KH. Hasyim Asyari semua cenderung menurun pada semua jenis kendaraan, seperti dapat terlihat dalam grafik di bawah ini :

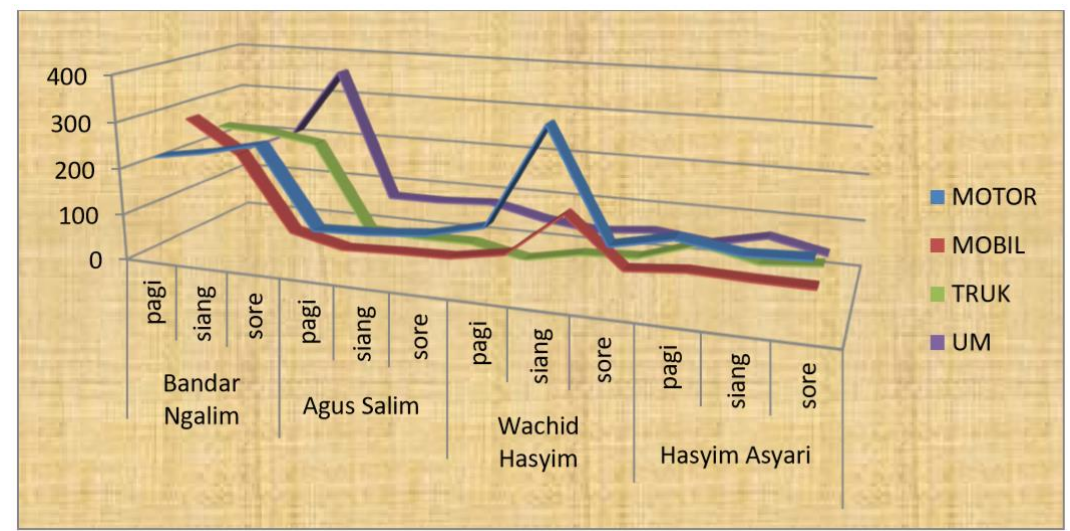

Gambar 1 Kepadatan Lalu Lintas Hari Libur

b. Visualisasi Kepadatan Lalu Lintas Hari Senin (kepadatan minimum)

Peningkatan jumlah kendaraan di jalanan pada hari kerja terlihat meningkat cukup tajam, jika dibandingkan pada hari libur maka peningkatannya hampir 50\% [34], [35]. Visualisasi kepadatan pada hari efektif peningkatan cukup signifikan bahkan pada jalan KH. Hasyim Asy'ari tingkat kepadatan sudah klasifikasi sangat padat yang didominasi sepeda motor. Pada semua jalan peningkatan jumlah sepeda motor juga mengalami peningkatan yang cukup tajam baik di jalan Bandar Ngalim, Jalan KH. Agus Salim maupun jalan KH. Wachid Hasyim. Sedangkan pada jenis kendaraan mobil peningkatan terlihat di jalan KH. Agus Salim dan Jalan KH. Wachid Hasyim, sedangkan pada jalan KH. Hasyim Asyari kepadatan jumlah mobil cenderung menurun. Penggunaan sepeda motor sebagai alat transportasi pada hari kerja memang banyak dipilih masyarakat, selain praktis sepeda motor juga terbilang hemat dalam konsumsi bahan bakar sehingga aktifitas dapat dengan mudah dilakukan seperti terlihat pada grafik berikut : 


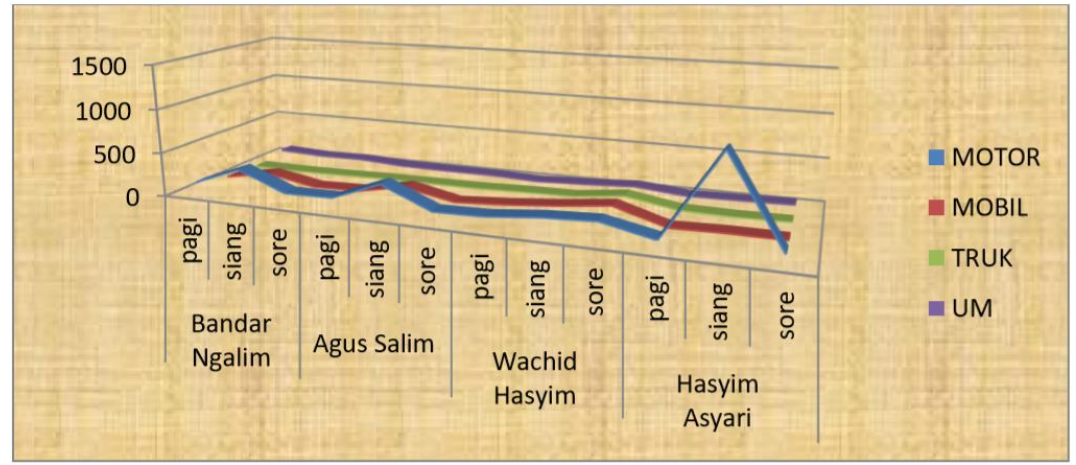

Gambar 2 Kepadatan Lalu Lintas Hari Kerja

Pada pagi hari volume kendaraan yang masuk ke arah jalan $\mathrm{KH}$. Wachid Hasyim ataupun menuju jalan KH. Agus Salim terbilang sangat tinggi dari arah jalan Bandar Ngalim. Biasanya volume kendaraan ini didominasi oleh aktifitas pelajar dan pekerja cukup tinggi yang menuju ke daerah kecamatan Mojoroto yang memang area sekolah dan perkantoran. Volume kendaraan dari arah jalan KH. Hasyim Asy'ari yang sangat tinggi pada hari efektif menuju arah jalan KH. Wachid Hasyim ataupun mengarah ke jalan Bandar Ngalim juga didominasi para pelajar dan para pekerja yang akan beraktifitas. Jalan KH. Hasyim Asy'ari yang merupakan akses dari daerah perbatasan kota dan kabupaten menjadi jalur yang efektif arus mobilisasi masyarakat sehingga volume kendaraan cukup tinggi.

2. Tingkat Kepadatan Persimpangan Bandar Kidul Menggunakan Metode Greenshields

Arus lalu lintas akan menjadi nol apabila kepadatan sangat tinggi sehingga tidak memungkinkan kendaraan akan bergerak lagi atau dikenal dengan kondisi macet total. Pada kondisi kepadatan nol, tidak terdapat kendaraan di ruas jalan sehingga arus lalu lintas juga nol [35]. Selain itu, pada kondisi kepadatan nol kendaraan akan bebas memilih kecepatannya sesuai dengan kondisi ruas jalan yang ada atau dikenal dengan kecepatan arus bebas.

a. Hubungan Matematis Antara Kecepatan dan Kepadatan

Menghitung hubungan antara volume (V) dan kecepatan (Us) dapat dilakukan dengan menggunakan persamaan dasar yang sudah dituliskan di atas dengan notasi rumus sebagai berikut :

Tabel 1 Hubungan Antara Kecepatan dan Kepadatan

\begin{tabular}{|l|l|l|l|}
\hline & & & \\
\hline atan (rata-rata) & -07.00 & -13.00 & -17.00 \\
\hline 3 Juli 2017 & 75 & 59 & 42 \\
& 07 & 00 & 57 \\
& 42 & 17 & 59 \\
\hline 1, 2 Juli 2017 & 75 & 03 & 44 \\
& 1 & 9 & 80 \\
& 52 & 98 & 05 \\
\hline
\end{tabular}

b. Hubungan Matematis Antara Volume dan Kecepatan

Menghitung hubungan antara volume (V) dan kepadatan (Dj) dapat dilakukan dengan menggunakan persamaan dasar yang sudah dituliskan di atas dengan notasi rumus sebagai berikut : 
Tabel 2 Hubungan Antara Volume dan Kecepatan

\begin{tabular}{|l|l|}
\hline hatan (Senin, 3 Juli 2017) & hatan (Minggu, 2 Juli 2017) \\
\hline a. Pengamatan (06.00-07.00) & a. Pengamatan (06.00-07.00) \\
V/Us & V/Us \\
$78,75 / 5,107$ & $29,75 / 1,61$ \\
15,42 & 18,52 \\
b. Pengamatan (12.00-13.00) & b. Pengamatan (12.00-13.00) \\
V/Us & V/Us \\
$55,59 / 2,900$ & $32,03 / 2,29$ \\
19,17 & 13,98 \\
c. Pengamatan (16.00-17.00) & c. Pengamatan $(16.00-17.00)$ \\
V/Us & V/Us \\
$50,42 / 2,457$ & $30,74 / 1,180$ \\
24,59 & 26,05 \\
\hline
\end{tabular}

c. Hubungan Matematis Antara Volume dan Kepadatan

Berdasarkan hasil analisis karakteristik kendaraan dengan menggunakan metode Greenshield pada hari Senin pagi 3 Juli 2017, dengan rumus sebagai berikut :

$$
V m=\frac{D j . U f}{4}
$$

$V m=\frac{15,42 \cdot 78,75}{4}=303,58 \mathrm{smp} / \mathrm{jam} / \mathrm{lajur}$

Keterangan :

$\mathrm{Vm}=$ arus maksimum $(\mathrm{km} / \mathrm{jam})$

$\mathrm{Dj}=$ kepadatan kondisi jam $(\mathrm{smp} / \mathrm{km})$

$\mathrm{Uf}=$ kecepatan pada kondisi arus bebas $(\mathrm{km} / \mathrm{jam})$

Berdasarkan hasil analisis karakteristik kendaraan dengan metode Greenshields pada hari Senin, pagi 3

Juli 2017, dengan rumus sebagai berikut :

$V m=\frac{26,05 \cdot 30,74}{4}=200,19 \mathrm{smp} /$ jam/lajur

$$
V m=\frac{D j . U f}{4}
$$

Berdasarkan perhitungan didapat bahwa hari Senin pagi arah masuk dari Jalan Bandar Ngalim merupakan volume maksimum yang terbesar terjadi yaitu Vmax sebesar 303,58 smp/jam/lajur menuju jalan

KH. Wachid Hasyim dan jalan KH. Agus Salim sedangkan volume maksimum pada jalan Bandar Ngalim terjadi pada hari Minggu Sore yaitu Vmax sebesar 200,19 Smp/Jam/lajur.

3. Kapasitas Arus Persimpangan Bandar Kidul Menggunakan Metode Webster

Asumsi dasar dalam perhitungan teori F.V Webster adalah bahwa kedatangan kendaraan terjadi secara seragam. Berdasarkan asumsi tersebut F.V Webster mengembangkan persamaan klasik untuk menghitung penundaan rata-rata per kendaraan ketika mendekati persimpangan dan juga menurunkan sebuah persamaan untuk memperoleh waktu siklus maksimum yang menghasilkan penundaan kendaraan minimum [22], [23]. Penundaraan kendaraan terjadi karena jumlah kendaraan yang masuk ke dalam sebuah persimpangan lebih besar dibandingkan dengan jumlah kendaraan yang keluar dari persimpangan tersebut.

Selanjutnya untuk kepadatan kendaraan yang sama, grafik waktu-nyala lampu hijau dan lampu merah pada fase 1 berpotongan dengan fase 2 begitupun juga dengan fase 3 dan fase 4 . Hal tersebut dapat diartikan bahwa waktu-nyala lampu hijau dan lampu merah pada fase 1 dan fase 2 akan sama ketika kepadatan kendaraannya sama untuk semua fase. Namun pada kasus ini, meskipun kepadatan kendaraan sama, porsi lamanya waktu-nyala lampu hijau akan berkurang untuk fase dengan lebar jalan yang lebih luas sedangkan lamanya waktu-nyala lampu merah akan bertambah untuk fase dengan jalan yang lebih lebar. Dapat disimpulkan, nyala lampu hijau dan lampu merah 
menggunakan metode Webster ini tergantung pada volume kendaraan. Semakin padat jumlah kendaraan, semakin panjang pula lamanya waktu-nyala lampu hijau dan lampu merah. Selain kepadatan kendaraan, lebar jalan pun memberikan sumbangan dalam penentuan siklus optimum. Semakin padat jumlah kendaraan, semakin panjang waktu dari siklus optimum.

Terdapat empat fase yang digunakan pada simulasi dan kondisi sekarang. Kisaran banyaknya kendaraan per jam dari tiga kondisi tersebut adalah sebagai berikut. Cukup padat $(\mathrm{CP})=$ 400-700 smp/jam Padat $(\mathrm{P})=701-1000 \mathrm{smp} / \mathrm{jam}$ Sangat padat $(\mathrm{SP})=$ lebih dari $1000 \mathrm{smp} / \mathrm{jam}$.

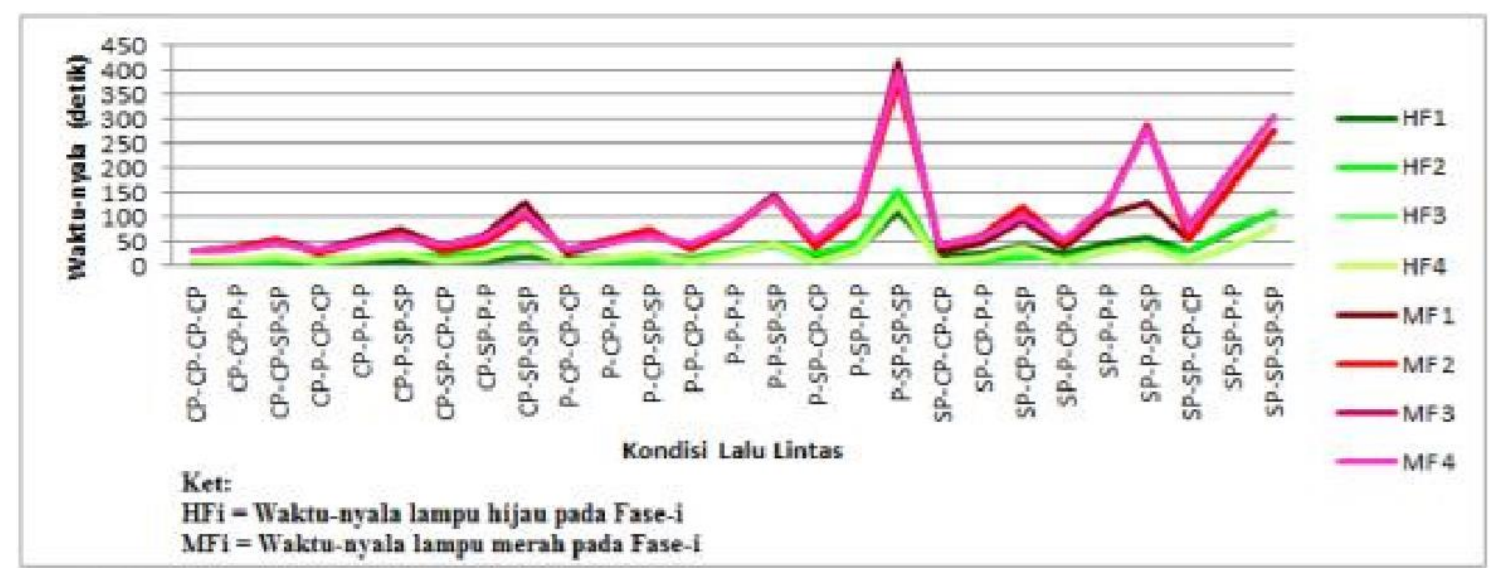

Gambar 3 Waktu-Nyala Lampu Lalu Lintas Menggunakan Metode Webster dengan Lebar Jalan Lebih Luas di fase 3 dan fase 4

Selanjutnya metode Webster akan diterapkan untuk menentukan lamanya waktu-nyala lampu lalu lintas di persimpangan Bandar Kidul Kota Kediri. Di persimpangan ini, terdapat 4 fase, setiap fase memberikan aturan terkait jalur mana yang boleh dilewati oleh kendaraan di persimpangan. Uraian dari 4 fase tersebut sebagai berikut.

a. Fase 1: Jalur utara ke selatan, utara ke timur, serta utara ke barat yang berturut-turut menghubungkan Jalan KH. Wachid Hasyim dan Jalan KH. Hasyim Asy'ari, Jalan KH. Wachid Hasyim dan Jalan Bandar Ngalim serta Jalan KH. Wachid Hasyim dan Jalan KH. Agus Salim.

b. Fase 2: Jalur selatan ke utara, selatan ke barat serta selatan ke timur yang berturut-turut menghubungkan Jalan KH. Hasyim Asyari dan Jalan KH. Wachid Hasyim, Jalan KH. Hasyim Asy'ari dan Jalan KH. Agus Salim serta Jalan KH. Hasyim Ays'ari dan Jalan Bandar Ngalim.

c. Fase 3: Jalur timur ke barat, timur ke selatan, serta timur ke utara yang berturut-turut menghubungkan Jalan Bandar Ngalim dan KH. Agus Salim, Jalan Bandar Ngalim dan Jalan KH. Hasyim Asy'ari serta Jalan Bandar Ngalim dan KH. Wachid Hasyim.

d. Fase 4: Jalur barat ke timur, barat ke utara serta barat ke selatan yang berturut-turut menghubungkan Jalan KH. Agus Salim dan Jalan Bandar Ngalim, Jalan KH. Agus Salim dan Jalan KH. Wachid Hasyim serta Jalan KH. Agus Salim dan Jalan KH. Hasyim Asyari.

Lebar jalan jalur utara-selatan adalah 7.5 meter dan lebar jalan jalur barat 9.89 meter sedangkan lebar jalan lajur timur 12 meter. Penulis mengambil data banyaknya kendaraan selama 2 hari berturutturut, yakni hari Minggu dan Senin tanggal 2-3 Juli 2017, pagi pukul 06.12-07.00WIB siang pukul 12.00-12.54WIB, sore pukul 16.00-17.00WIB, dengan asumsi bahwa jumlah kendaraan pada hari-hari lain telah disebutkan adalah sama.

Berdasarkan hasil yang diperoleh, tipe dari kondisi lalu lintas di Bandar Kidul adalah cukup padat (CP) di jalur utara-selatan, cukup padat (CP) di jalur selatan-utara, sangat padat (SP) di jalur timurbarat dan sangat padat (SP) di jalur barat-timur. Menggunakan metode Webster, diperoleh hasil untuk minggu ke-1, yaitu waktu-nyala lampu hijau pada jalur utara atau fase 1 sebesar 29,37 detik, waktunyala lampu hijau pada jalur selatan atau fase 2 sebesar 29,98 detik, waktu-nyala lampu hijau pada 
jalur timur atau fase 3 sebesar 31,56 detik dan waktu-nyala lampu hijau pada jalur barat atau fase 4 sebesar 31,33 detik. Sedangkan untuk waktu-nyala lampu merah pada jalur utara atau fase 1 sebesar 97.80 detik, waktunyala lampu merah pada jalur selatan atau fase 2 sebesar 97.20 detik, waktu-nyala lampu merah pada jalur timur atau fase 3 sebesar 95.69 detik, dan waktu-nyala lampu merah pada fase barat atau fase 4 sebesar 95.80 detik.

Setelah dilakukan perbandingan antara perhitungan menggunakan metode Webster berbeda dengan waktu-nyala lampu merah dan hijau di persimpangan Bandar Kidul Kediri. Berikut adalah lamanya waktu-nyala lampu hijau dan merah sebagai berikut:

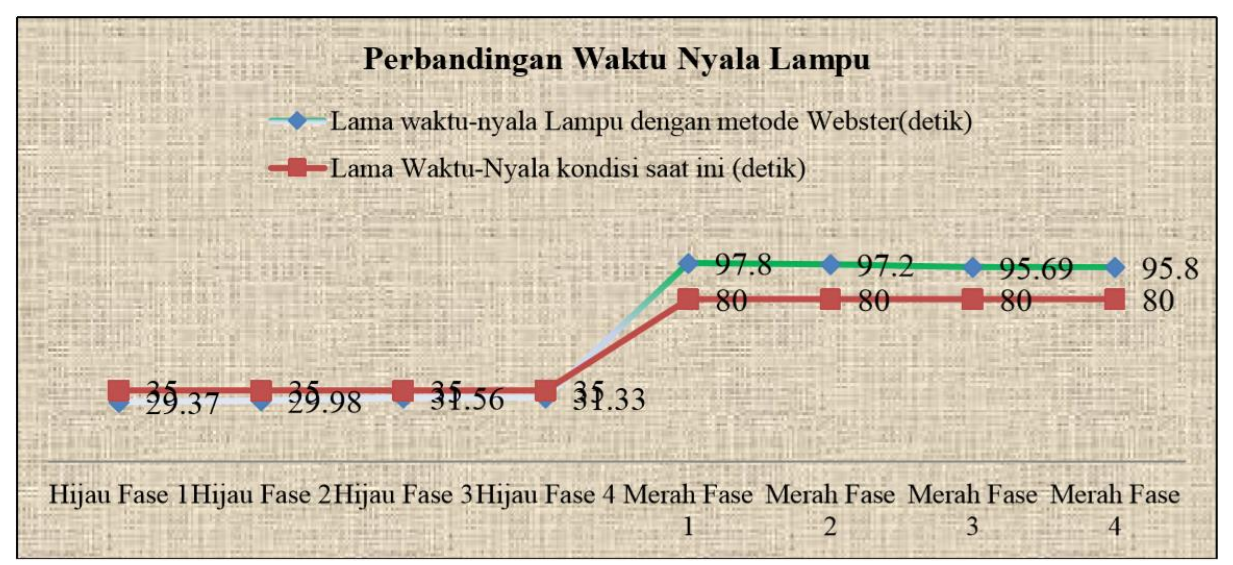

Gambar 4 Perbandingan Waktu-Nyala Lampu Lintas di Persimpangan Bandar Kidul Kediri

Perhitungan dengan metode Webster menghasilkan perhitungan yang berbeda-beda pada setiap fase. Hal tersebut dapat dijadikan alternatif dalam mengatur lama waktu menyala mengingat beban jalan pada tiap fase memang berbeda-beda, jalan dengan volume tinggi seharusnya mendapatkan porsi menyala lampu lebih lama sehingga mengurangi antrian kendaraan di persimpangan. Dalam pemilihan sebuah kasus, Webster mengambil rata-rata persimpangan yang secara umum adalah yang memiliki rasio y antara 1:1 dan 2:1 serta arus jenuh antara 1500 dan 3000. Dapat dilihat, pada arus jenuh 1500 dan 3000, nilai K adalah 1.31 dan 1.70. Sehingga nilai $\mathrm{K}$ untuk satu fase persimpangan adalah rata-rata dari kedua nilai $\mathrm{K}$, yaitu $\mathrm{K}=1.50$.untuk melihat simulasi lebih lengkap dapat dilihat pada tabel 4.16 mengenati simulasi banyaknya kendaraan yang melintas di setiap jalur menunju persimpangan. Selanjutnya pada tabel 4.17 untuk melihat simulasi waktu nyala lampu lalu lintas pada fase 3 dan fase 4 . Analisis pada siklus minimum di persimpangan Bandar Kidul dihitung dengan menjumlahkan waktu hilang (L) dengan jumlah waktu yang diperlukan untuk melewati persimpangan pada tingkat kemungkinan maksimum. Siklus minimum dapat diartikan sebagai siklus dimana semua lalu lintas yang tiba dalam satu siklus melewati persimpangan dalam siklus yang sama.

Berdasarkan penelitian yang dilakukan oleh Webster, ditemukan bahwa panjang siklus optimum kurang lebih sama dengan dua kali siklus minimum,sehingga siklus optimum didekati menjadi. Kemudian L diganti dengan $\frac{c o(1-Y)}{2}$ hanya untuk penyederhanaan. Pada persamaan total lamanya penundaan kendaraan minimum untuk persimpangan $\mathrm{n}$ fase, $\mathrm{L}$ yang memiliki pangkat lebih tinggi dari satu disederhanakan. Hasil hitunga menunjukkan bahwa variabel F merupakan sebuah faktor yang bergantung pada arus, arus jenuh dan waktu hilang pada persimpangan. Nilai dari faktor $F$ ini cukup dekat ke satu. Selanjutnya dilakukan analisis untuk mengetahui nilai Z, dengan menyusun kembali persamaan untuk E, E sebagai fungsi dari (Gyr) terhadap yr dimana $\mathrm{G}=\frac{3-Y}{2 Y}$. Nilai $\mathrm{E}$ tidak dapat diketahui secara akurat karena terdapat error/galat. 1\% error pada E menghasilkan hampir $0,2 \%$ error pada siklus optimum.Dengan mensubstitusikan nilai $\mathrm{E}$ yang telah diperoleh dari persamaan sebelumnya, diperoleh nilai $\mathrm{F}$ baru sebagai berikut : 


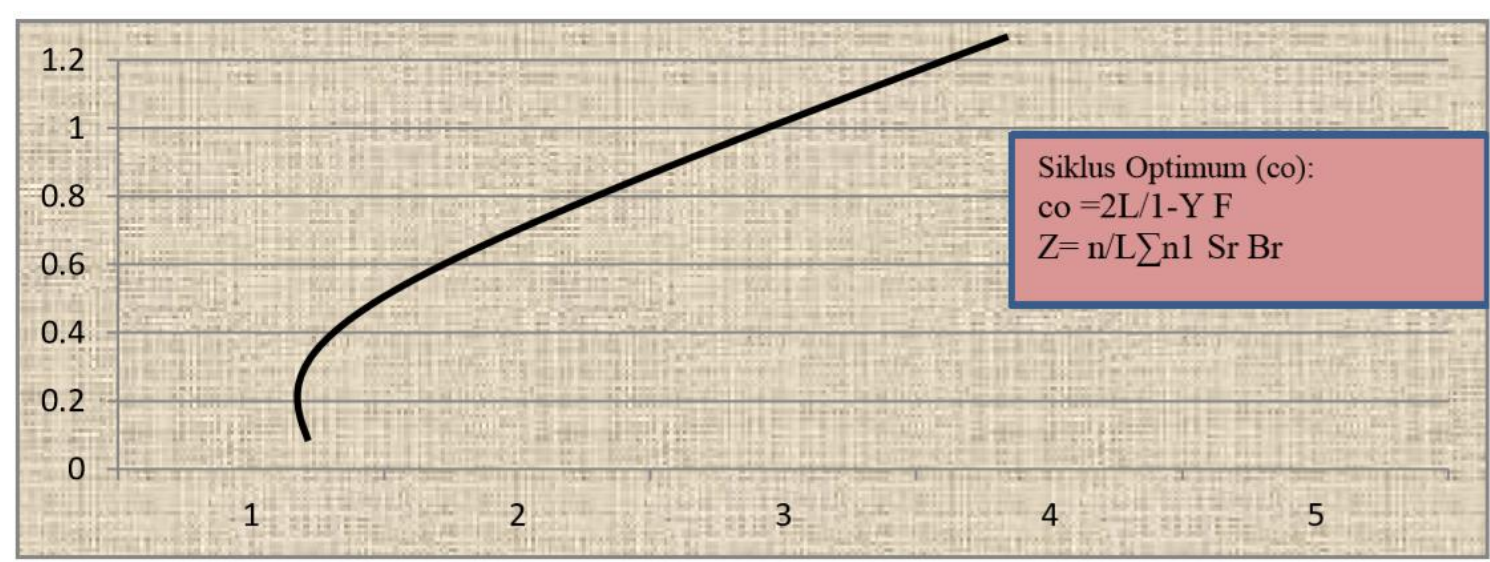

Gambar 5 Grafik siklus optimum, faktor F

Dari ke-9 nilai $\mathrm{F}$ yang telah ditemukan, hanya 3 nilai $\mathrm{F}$ yang akan dipakai, yakni nilai $\mathrm{F}$ yang berada di rasio 3:1 pada rata-rata arus jenuh 1200, rasio 2:1 pada rata-rata arus jenuh 1800 dan rasio 1:1 pada rata-rata arus jenuh 3600. Perhitungan dengan model Webster menghasilkan perhitungan yang berbeda-beda pada setiap fase. Hal tersebut dapat dijadikan alternatif dalam mengatur lama waktu menyala mengingat beban jalan pada tiap fase memang berbeda-beda, jalan dengan volume tinggi seharusnya mendapatkan porsi menyala lampu lebih lama sehingga mengurangi antrian kendaraan di persimpangan.

Seperti pada jalan KH. Agus Salim dari arah barat yang biasanya memiliki kepadatan arus cukup panjang bahkan jika terjadi arus puncak kepadatan kendaraan bisa mencapai 200 meter dari traffic light, mengingat waktu nyala lampu hijau yang pendek dengan kecepatan kendaraan dibawan $20 \mathrm{~km} / \mathrm{jam}$ maka tidak mungkin meloloskan semua kendaraan, tidak imbangnya kendaraan yang keluar persimpangan dengan kendaraan yang datang menyebabkan antrian yang cukup panjang. Salah satu alternatif bisa menggunakan perpanjangan waktu nyala lampu untuk Jalan KH. Agus Salim, serta melakukan pengaturan sepeda motor berada di jalur terdepan traffic light seperti yang diterapkan di perempatan alun-alun. Selain itu larangan becak atau parkir kendaraan pada bahu jalan di jalur kiri Jalan KH. Agus Salim juga akan mempercepat arus lalu lintas kendaraan yang akan belok ke kiri menuju Jalan KH. Wachid Hasyim. Ataupun kendaraan roda empat dapat melakukan antrian dengan dua jalur sehingga akan memperpendek panjang antrian ke belakang.

Jalan Bandar Ngalim merupakan jalan terlebar diantara ketiga jalan yang lain, namun demikian lebarnya jalan tanpa pengaturan pada kendaraan yang akan belok ke kanan menuju jalan KH. Wachid Hasyim terutama kendaraan sepeda motor menyebabkan antrian berada di sebelah kanan dan melewati marka jalan, tentu hal ini melanggar lalu lintas dan mempersempit arus dari arah jalan lain yang menuju ke Jalan Bandar Ngalim, maka diperlukan pengaturan untuk menempatkan sepeda motor di antrian terdepan seperti pada rekomendasi pada jalan KH. Agus Salim. Kendaraan yang akan belok ke kiri dapat langsung mengambil arah menunju jalan KH. Hasyim Asy'ari.

Pada Jalan KH. Wachid Hasyim rekomendasi yang dapat diberikan adalah pelebaran jalan, mengingat arus dari jalan KH. Agus Salim yang langsung belok kiri akan bertemu langsung dengan kendaraan dari Jalan Bandar Ngalim ataupun kendaraan dari Jalan KH. Hasyim Asy'ari ketika pada masing-masing fase ini lampu hijau menyala. Pada fase Jalan KH. Wachid Hasyim juga diperlukan pemberian marka khusus penempatan sepeda motor pada antrian terdepan, untuk mengurangi antrian pada sisi kanan kendaraan yang akan belok kanan menuju Jalan KH. Agus Salim, sepeda motor yang antri kadangkala juga melebihi batas marka jalan sehingga jalan menyempit, menyebabkan arus kecepatan kendaraan menurun.

Jalan KH. Hasyim Asyari yang padat pada pagi hari karena arus kendaraan masyarakat yang akan berangkat kerja atapun pelajar yang akan sekolah, memerlukan pelebaran jalan dan pengaspalan pada sisi kanan dan kiri jalan sehingga antrian kendaraan yang melewati batas marka sebelah kanan 
sehingga tidak menyebabkan jalan menyempit terutama kendaraan roda empat yang belok kiri langsung dari jalan Bandar Ngalim, biasanya melambat karena penyempitan antrian dari kendaraan di traffic light. Seperti pada jalur lain pada jalur ini juga diperlukan pengaturan penempatan sepeda motor berada di barisan terdepan, mengingat tingginya arus kendaraan sepeda motor dari jalan ini menuju ke jalan KH. Wachid Hasyim ataupun ke jalan Bandar Ngalim.

\section{Kesimpulan}

Berdasarkan hasil analisis data pada bab sebelumnya, maka penelitian ini dapat disimpulkan sebagai berikut:

1. Berdasarkan hasil yang diperoleh, tipe dari kondisi lalu lintas di Bandar Kidul adalah cukup padat (CP) Jalan KH. Wachid Hasyim menuju Jalan KH. Hasyim Asy'ari), cukup padat (CP) di jalur Jalan KH. Hasyim Asy'ari menuju Jalan KH. Wachid Hasyim, sangat padat (SP) di Jalan Bandar Ngalim menuju Jalan KH. Agus Salim dan sangat padat (SP) di Jalan KH. Agus Salim menuju Jalan Bandar Ngalim.

2. Berdasarkan analisis menggunakan metode Greenshields diperoleh model hubungan antar karakteristik volume (q), kecepatan (v), kerapatan (k) dan volume maksimum (Vmax). Didapatkan temuan bahwa hari Senin pagi arah masuk dari Jalan Bandar Ngalim merupakan volume maksimum yang terbesar terjadi yaitu Vmax sebesar 303,58 smp/jam/lajur menuju jalan $\mathrm{KH}$ Wachid Hasyim dan jalan KH Agus Salim sedangkan volume maksimum pada jalan Bandar Ngalim terjadi pada hari Minggu Sore yaitu Vmax sebesar 191,51 Smp/Jam/lajur.

3. Berdasarkan analisis menggunakan metode Webster, waktu-nyala lampu hijau pada jalur utara atau fase 1 sebesar 29,37 detik, waktu-nyala lampu hijau pada jalur selatan atau fase 2 sebesar 29,98 detik, waktu-nyala lampu hijau pada jalur timur atau fase 3 sebesar 31,56 detik dan waktu-nyala lampu hijau pada jalur barat atau fase 4 sebesar 31,33 detik. Sedangkan untuk waktu-nyala lampu merah pada jalur utara atau fase 1 sebesar 97,80 detik, waktu-nyala lampu merah pada jalur selatan atau fase 2 sebesar 97,20 detik, waktu-nyala lampu merah pada jalur timur atau fase 3 sebesar 95,69 detik, dan waktu-nyala lampu merah pada fase barat atau fase 4 sebesar 95,80 detik.

\section{Daftar Pustaka}

[1] A. Novikov, I. Novikov, A. Katunin, and A. Shevtsova, "Adaptation Capacity of the Traffic Lights Control System (TSCS) as to Changing Parameters of Traffic Flows Within Intellectual Transport Systems (ITS)," Transp. Res. Procedia, vol. 20, no. September 2016, pp. 455-462, 2017.

[2] O. Rafif, A. Aziz, and H. M. Asih, "Developing Hybrid Simulation Model to Improve Road Traffic Management," vol. 01, pp. 56-65, 2020.

[3] D. Branston and H. Zuylen, "The estimation of saturation flow, effective green time and passenger car equivalents at traffic signals by multiple linear regression," Transp. Res., vol. 12, no. 1, pp. 47-53, 1978.

[4] T. Tsuboi and N. Yoshikawa, "Traffic flow analysis in Ahmedabad (India)," Case Stud. Transp. Policy, vol. 8, no. 1, pp. 215-228, 2019.

[5] S. Salini and R. Ashalatha, "Analysis of traffic characteristics of urban roads under the influence of roadside frictions," Case Stud. Transp. Policy, vol. 8, no. September 2016, pp. 94-100, 2018.

[6] S. J. A. Wesli, “Kajian Kebutuhan Lampu Lalu Lintas Pada Simpang 6,” vol. 3, no. 2, pp. 118 127, 2016.

[7] A.- Desmi, L. A. Widari, and R. Yanti, "Efektifitas Model Karakteristik Arus Lalu Lintas Pada Ruas Jalan Simpang 4 Bireun (Perbandingan Dengan Metode Greenshield, Greenberg, Underwood)," Teras J., vol. 9, no. 1, p. 19, 2019.

[8] E. N. Julianto, "Hubungan Antara Kecepatan, Volume Dan Kepadatan Lalu Lintas Ruas Jalan 
Siliwangi Semarang," Hub. Antara Kecepatan, Vol. Dan Kepadatan Lalu Lintas Ruas Jalan Siliwangi Semarang, vol. 12, no. 2, pp. 151-160, 2010.

[9] N. L. W. R. Kurniati, "Optimalisasi Kinerja Simpang Pasar Pagi Arenka Di Kota Pekanbaru Performance Optimation on the Intersection of Arenka Market in the City of Pekanbaru," Transp. Res., no. 5, pp. 133-146, 2016.

[10] A. Kotov and P. Pospelov, "Engineering Tools and Methods of Estimation of Traffic Capacity Using Mobile Video Monitoring," Transp. Res. Procedia, vol. 20, no. September 2016, pp. $347-$ 354, 2017.

[11] S. Bernardi and F. Rupi, "An analysis of bicycle travel speed and disturbances on off-street and on-street facilities," Transp. Res. Procedia, vol. 5, pp. 82-94, 2015.

[12] W. Widodo, N. Wicaksono, and Harwin, "Analisis Volume, Kecepatan , dan Kepadatan Lalu Lintas dengan Metode Greenshields dan Greenberg," J. Ilm. Semesta Tek., vol. 15, no. 2, pp. 178-184, 2012.

[13] B. M. D. Jenderal, Manual Kapasitas Jalan Indonesia (MKJI). Jakarta: Departemen Pekerjaan Umum, 1997.

[14] D. Satriaputri and E. R. Cahyadi, "Analisis Risiko Operasional Jalan Tol Jagorawi PT Jasa Marga (Persero) Tbk," J. Manaj. dan Organ., vol. 6, no. 3, p. 258, 2016.

[15] R. Apriliyanto and T. Sudibyo, "Analisis Kemacetan Dan Perkiraan Tingkat Pelayanan Jalan Pada Masa Mendatang (Studi Kasus Jalan Raya Sawangan Depok)," Anal. Kemacetan Dan Perkiraan Tingkat Pelayanan Jalan Pada Masa Mendatang (Studi Kasus Jalan Raya Sawangan Depok), vol. 3, no. 2, pp. 105-116, 2018.

[16] J. Setiabudhi et al., "Analisis Kinerja Simpang," Fak. Tek. Sipil dan Lingkungan, Inst. Teknol. Bandung, no. 1506134, pp. 1-11, 2012.

[17] E. P. Kulo, S. Y. R. Rompis, and J. A. Timboeleng, "Analisis Kinerja Simpang Tak Bersinyal Dengan Analisis Gap Accaptance Dan MKJI 1997,” J. Sipil Statik Vol.5, vol. 5, no. 2, 2017.

[18] A. Banerjee, A. K. Maurya, and G. Lämmel, "Pedestrian flow characteristics and level of service on dissimilar facilities: A critical review," Collect. Dyn., vol. 3, pp. 1-52, 2018.

[19] T. Tharbainti, M. Soleh, and M. N. Muhaijir, "Analisis Model Hubungan Karakteristik Lalu Lintas dan Tingkat Pelayanan Jalan pada Persimpangan Tiga Tabek Gadang Pekanbaru," vol. 3, no. 2, pp. 1-7, 2017.

[20] A. S. Lubis, Z. A. Muis, and T. Nasution, "Pemodelan Hubungan Parameter Karakteristik Lalu Lintas pada Jalan Tol Belmera," Media Komun. Tek. Sipil, vol. 22, no. 2, p. 151, 2016.

[21] Y. Dwitama, "Studi Indeks Tingkat Pelayanan Jalan Sukarno Hatta Kota Palembang Dengan Metode Greenshield Pada Kondisi Siang Dan Malam Hari Dengan Pencahayaan Lampu Jalan," J. Tek. Sipil dan Lingkung., vol. 2, no. 3, p. pp.592-602, 2014.

[22] B. Webster, FV dan Cobbe, Traffic Signals. London: HMSO, 2009.

[23] I. W. Kustanrika, "PERHITUNGAN SINYAL PADA SIMPANG DENGAN METODE WEBSTER," J. Kaji. Ilmu dan Teknol., vol. 53, no. 9, pp. 1689-1699, 2013.

[24] N. Holeczek, "Hazardous materials truck transportation problems: A classification and state of the art literature review," Transp. Reserach Part D Transp. Environ., vol. 69, pp. 305-328, 2019.

[25] O. Tamin, Perencanaa Pemodelan dan Transportasi. Bandung: Institut Teknologi Bandung, 
2000.

[26] A. Swanto, H. D. S. Simanjuntak, M. S. Surbakti, and D. Ph, "Analisis Perbandingan Critical Gap Pada U-Turn Dengan Beberapa Variasi Metode ( Studi Kasus : J1 . Gagak Hitam Depan Home Centra Medan ).”

[27] Sugiyono, "Teknik Pengumpulan Data," Metod. Penelit. Kuantitatif, Kualitatif dan R\&D, p. 137, 2014.

[28] Sugiyono, "Metode Penelitian Kombinasi (Mixed Methods)," Bandung Alf., 2010.

[29] Sugiyono, Metode Penelitian Kuantitatif Kualitatif dan R\&D. Bandung: Alfabeta, 2012.

[30] I. Agusta, "Teknik Pengumpulan dan Analisis Data Kualitatif," J. Stud. Komun. dan Media, vol. 02, no. 1998, pp. 1-11, 2014.

[31] A. Heryana, "Kerangka Teori, Kerangka Konsep, Variabel Penelitian, Dan Hipotesis Penelitian (Dalam Penelitian Kuantitatif)," Metodol. Penelit., 2015.

[32] H. Yustianingsih and Istianah, "KAJIAN KORELASI TINGKAT KEPADATAN LALU LINTAS DI KOTA SEMARANG DENGAN KONSENTRASI CO DAN Pb,” Untidar, vol. 01, pp. 19-24, 2017.

[33] M. Isya et al., "Analisis Hubungan Antara Volume, Kecepatan Dan Kepadatan Lalu Lintas (Studi Kasus: Jembatan Lamnyong, Jalan Teuku Nyak Arief Banda Aceh)," J. Tek. Sipil, vol. 5, no. 3, pp. 279-290, 2016.

[34] H. Wibisana and N. Utono, "Pemetaan Kecepatan dan Kerapatan Lalu Lintas di Ruas Jalan Arteri Kota Surabaya," J. Tek. Sipil, vol. 12, no. 2, pp. 121-145, 2019.

[35] R. Gamran, F. Jansen, M. J. Paransa, and K. Kunci, "Analisa Perbandingan Perhitungan Kapasitas Menggunakan Metode Greenshields, Greenberg, Dan Underwood Terhadap Perhitungan Kapasitas Menggunakan Metode Mkji 1997,’ J. Sipil Statik, vol. 3, no. 7, pp. 466474, 2015. 